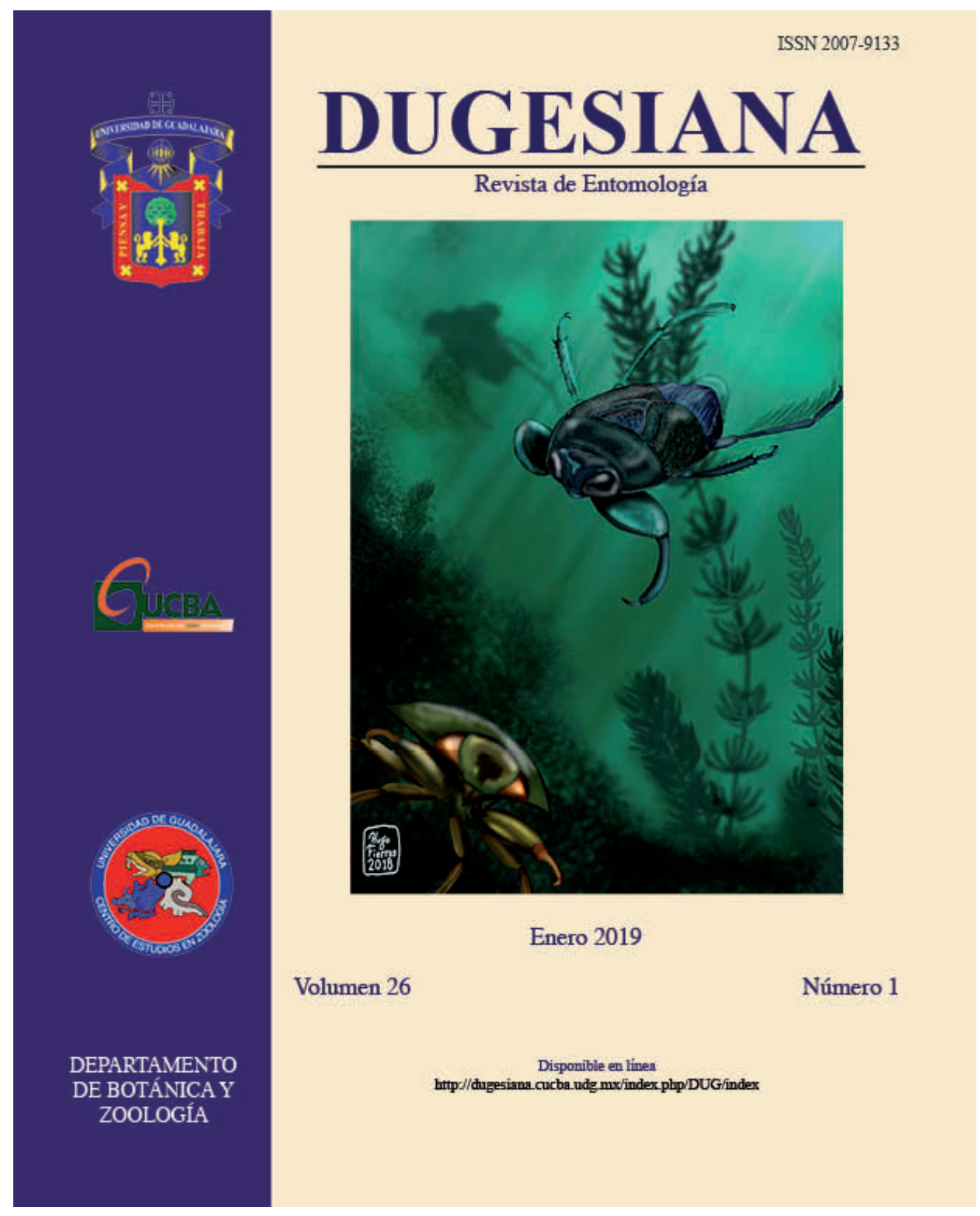

DUGESIANA, Año 26, No.1, 2019 (primer semestre de 2019) es una publicación Semestral editada por la Universidad de Guadalajara, a través del Centro de Estudios en Zoología, por la División de Ciencias Biológicas y Ambientales, CUCBA. Km. 15.5 carr. a Nogales, Predio Las Agujas s/n, Nextipac, C.P. 45100. Zapopan, Jalisco, México. Tel. 37771150, http://dugesiana.cucba.udg.mx/index.php/DUG/index, glenusmx@gmail.com, Editor responsable: José Luis Navarrete Heredia. Reserva de Derechos al Uso Exclusivo 04-2009-062310115100-203, ISSN: 2007-9133, otorgados por el Instituto Nacional del Derecho de Autor. Responsable de la última actualización de este número: José Luis Navarrete Heredia, Editor y Ana Laura González-Hernández, Asistente Editorial. Fecha de la última modificación 1 de enero de 2019, con un tiraje de un ejemplar.

Las opiniones expresadas por los autores no necesariamente reflejan la postura del editor de la publicación.

Queda estrictamente prohibida la reproducción total o parcial de los contenidos e imágenes de la publicación sin previa autorización de la Universidad de Guadalajara. 


\title{
Two new Mexican species of Pharaxonotha Reitter, 1875 (Coleoptera: Erotylidae) from Ceratozamia tenuis (Cycadales: Zamiaceae)
}

\author{
Dos nuevas especies mexicanas de Pharaxonotha Reitter, 1875 (Coleoptera: Erotylidae) en Ceratozamia \\ tenuis (Cycadales: Zamiaceae)
}
Santiago-Jiménez, Quiyari J.1*, Martínez-Domínguez, Lilíi and Nicolalde-Morejón, Fernando ${ }^{2}$
${ }^{1}$ Facultad de Biología, Universidad Veracruzana, Xalapa, 91090, Veracruz. México. Email: qsantiago@uv.mx; ${ }^{2}$ Laboratorio de Taxonomía Integrativa, Instituto de Investigaciones Biológicas, Universidad Veracruzana, Xalapa, 91190, Veracruz. México. Email: enicolalde@uv.mx, lilimartinezd@gmail.com·*Corresponding author

\section{RESUMEN}

Dos nuevas especies de Pharaxonotha Reitter, 1875 son descritas desde México. Ilustraciones y una clave para identificar las especies conocidas de Pharaxonotha del Nuevo Mundo son dadas. El género Ceratozamia Brongn (Zamiaceae) se registra como hospedero de Pharaxonotha mexicana sp. nov. y P. tenuis sp. nov. por primera vez. Los especímenes fueron colectados directamente en los conos de machos y hembras de C. tenuis.

Palabras clave: Pharaxonothinae, México, cícadas, estróbilo polinífero.

\section{ABSTRACT}

Two new species of Pharaxonotha Reitter, 1875 are described from Mexico. Illustrations are provided, as a key to identify Pharaxonotha known from the New World. The genus Ceratozamia Brongn (Zamiaceae) is recorded as a host to Pharaxonotha mexicana sp. nov. y P. tenuis sp. nov. for the first time. Specimens were collected directly in the cones of males and females of $C$. tenuis.

Keywords: Pharaxonothinae, Mexico, cycad, pollen strobilus.

The family Erotylidae (Latreille), currently combined with Languriidae (Wiedeman), includes approximately 3500 species worldwide, distributed in about 260 genera (Leschen 2003; Leschen et al. 2010; Slipinski et al. 2011). This family encompasses herbivorous (Languriinae Crotch) and fungivorous (Erotylini Latreille) forms, whereas other species can be scavengers, feeding on plant and fungus tissues (Leschen 2003). Currently, Erotylidae comprises six subfamilies: Cryptophilinae Casey, Languriinae Crotch, Xenoscelinae Ganglbauer, Pharaxonothinae Crowson, Loberinae Bruce and Erotylinae Latreille (Leschen, 2003). Pharaxonothinae includes the genus Pharaxonotha Reitter, 1875, which contains 14 species (Leschen 2003; Chaves and Genaro 2005; Franz and Skelley 2008; Skelley et al. 2017); however, two species distributed in Asia were recently assigned to the genus Cycadophila Xu, Tang, Skelley, 2015: C. nigra (Gorham, 1895) and C. yunnanensis (Grouvelle, 1916) (Xu et al. 2015). Subsequently, Skelley et al. (2017) included another four species, also distributed in Asia, in the Cycadophila genus: C. (C.) lata (Grouvelle, 1916), C. (C.) discimaculata (Mader, 1939), C. (C.) intermedia (Chûjô, 1967), and C. (C.) vittata (Arrow, 1925), based on a combination of character states (see below).

At present, 21 species of Cycadophila have been described, all of which are from Asia. In the New World, only 6 species of Pharaxonotha are recognized: two occur in Central America, Mexico, and the southeastern United States (Leschen and Skelley 2002), with two additional species in Costa Rica (Pakaluk 1988), one in Cuba (Chaves and Genaro 2005), and one in Puerto Rico (Franz and Skelley 2008). Pharaxonotha and two other genera of weevils are considered the primary pollinators of many Central America and Caribbean cycads (Franz and Skelley
2008). Most of the species of Pharaxonotha distributed in the New World have been found associated with the genus Zamia, and only one with Mycrocycas (Miq.) A. DC.: P. clarkorum Pakaluk, 1988 (Z. skinneri); P. confusa Pakaluk, 1988 (Z. fairchildeana); P. esperanzae Chaves and Genaro, 2005 (M. calocoma); P. floridana (Casey, 1890) (Z. pumila) and P. portophyla Franz \& Skelley, 2008 (Z. amblyphyllidia and $Z$. portoricensis); whereas, $P$. kirschii Reitter, 1875 is considered a pest of stored products (Pakaluk 1988; Chaves and Genaro 2005; Franz and Skelley 2008). To date, a few species of Pharaxonotha has been reported as associated with the genus Ceratozamia Brongn (Tang et al. 2018); moreover, the new species of Pharaxonotha described here were collected in the same host, $C$. tenuis. The objective of this study is therefore to describe the adults of two species of Pharaxonotha associated with this cycad.

\section{MATERIALS AND METHODS}

From 2015 to 2017, cones of C. tenuis were visited in the locality of Tlachinola, in the municipality of Coacoatzintla, Veracruz State, Mexico, in order to evaluate the development of reproductive structures in both sexes. During these trips, small beetles were found in the cones of both sexes. Insects were collected in small vials, preserved in $96 \%$ ethanol and taken to the laboratory. These insects were subsequently identified in the laboratory as members of Pharaxonotha. Most of the specimens collected were found in the male cones, and only a few in the female cones (see type material).

The specimens were observed using a Stemi DV4 stereomicroscope. Photographs illustrating structures in detail were taken using an image processing system (VELAB microscope model VE-633, with Digital LCD 
model DMS-153), and the images were merged using the image stacking software Combine ZP. Habitus photographs were taken through a Nikon SMZ25 stereoscopic microscope. Permanent microscope slides were prepared using the techniques described by Santiago-Jiménez (2010). The terminology used here mainly follows Franz and Skelley (2008), with some references to Chaves and Genaro (2005) and McHugh et al. (1997) for comparative purposes. However, the terms used for the adult male terminalia was based on Wanat (2007).

Type and paratype specimens are deposited in the following collections:

IEXA-Instituto de Ecología, A. C., Xalapa, Mexico (Ms. Sc. L. Delgado)

CNIN-Colección Nacional de Insectos, Instituto de Biología, Universidad Nacional Autónoma de México, Mexico City (Dr. S. Zaragoza)

\section{Systematics}

Leschen (2003) proposed three characters to distinguish the Pharaxonothinae subfamily: 1) lateral pockets present on the mentum; 2) presence of multitubulate cuticular ducts on the pronotum; 3) abdominal calli absent. Recently, $\mathrm{Xu}$ et al. (2015) stated that some characters proposed by Leschen (2003) are unreliable for the subfamily distinction, for example: 1) pockets on the mentum, which are reduced or absent in Pharaxonotha; 2) cuticular glandular ducts of prothorax microtubate, only when present; 3) abdominal calli absent, which, in the dichotomus key of Leschen (2003), the alternative option is "usually present". These three characters therefore do not ensure that new taxa will be placed as Pharaxonothinae. It was therefore proposed to use a combination of two characters, i.e., the presence of a transverse occipital ridge and absence of abdominal calli, which occurs only in members of Pharaxonothinae.

More recently, $\mathrm{Xu}$ et al. (2015) and Skelley et al. (2017) were able to distinguish Cycadophila from other Pharaxonothinae using a combination of character states: 1) transverse occipital ridge present; 2) supraocular striae present; 3) presentation of a remnant of the submentalgular suture visible to variously depressed; 4) abdominal calli absent; 5) male genitalia with median lobe and tegmen twisted like a corkscrew, and spiculum gastrale asymmetrical; 6) wings with anal cell present. In this context, the specimens found in Tlachinola, Coacoatzintla belong to the Pharaxonothinae subfamily. However, some characters proposed by Xu et al. (2015) and Skelley et al. (2017), to distinguish Cycadophila from Pharaxonotha and other genera of Pharaxonothinae, are present in the specimens of both species described here; i.e., submentalgular area visible as depressed darkened area, often with row punctures and setae. We described the new species as belonging to Pharaxonotha since we consider that other characters used to distinguish the Cycadophila genus, such as male genitalia with median lobe and tegmen laterally flattened and slightly to strongly twisted (at least basally), will be only variation within the Pharaxonotha genus. Moreover, Cycadophila as defined by $\mathrm{Xu}$ et al. (2015) is only distributed in Asia, whereas Pharaxonotha is widely distributed in the Americas. More recently, Tang et al. (2018) mentioned a new genus associated with Ceratozamia, however it was undescribed in their study.
Key to the New World species of Pharaxonotha

(some characters in the key were based on Pakaluk 1988;

Chaves and Genaro 2005; Franz and Skelley 2008).

1. Eyes small, not prominent ventrally (Pakaluk 1988: Fig. 1), ratio of head width/ventral interocular distance to head width/dorsal interocular distance 1.1×; not cycad-associated P. kirschii Reitter

- Eyes large, prominent ventrally (Pakaluk 1988: Fig. 2), ratio of head width/ventral interocular distance to head width/dorsal interocular distance $>1.3 \times$; cycad-associated ..

2. Apex of parameres markedly asymmetrical (Pakaluk 1988: Fig. 7); known distribution southeastern United States of America; associated with Z. pumila P. floridana (Casey)

- Apex of parameres not asymmetrical or slightly asymmetrical, but never markedly asymmetrical as above (Pakaluk 1988: Figs. 8, 9); known distribution Mexico, Central America and Greater Antilles; associated with other cycads ........................................................................ 3 3. Head with a supraocular striae (Chaves and Genaro 2005: Fig. 1A); lacking marginal line at base of elytra; known distribution Cuba; associated with Mycrocycas calocoma P. esperanzae Chaves \& Genaro - Head without a supraocular striae (Fig. 1A); with marginal line at base of elytra; other distribution, not present in Cuba; not associated with Mycrocycas ...................................... 4 4. Length 2.1-2.4 mm; known host plant Zamia skinneri ...... P. clarkorum Pakaluk - Length $>2.7 \mathrm{~mm}$; associated to other cycads ............... 5 5. Length $\leq 3.6 \mathrm{~mm}$; associated with Zamia genus .......... 6 - Length $\geq 3.6 \mathrm{~mm}$; associated with Ceratozamia genus ...7 6 Elytron length/pronotal length 2.89-3.15; head width/ dorsal interocular distance 1.90-1.96; head width/ventral interocular distance 2.70-3.06; apex of ventral edge of median lobe asymmetrical (Pakaluk 1988: Fig. 9); known distribution Costa Rica; known host plant Zamia fairchildeana ................................. P. confusa Pakaluk -Elytron length/pronotal length 3.33 (range unknown); head width/dorsal interocular distance 1.55-1.73; head width/ ventral interocular distance 2.12-2.30; apex of ventral edge of median lobe symmetrical (Franz and Skelley 2008: Fig. 6); known distribution Puerto Rico; known host plants $Z$. amblyphyllidia and Z. portoricensis

P. portophylla Franz \& Skelley

7. Elytron length/pronotal length 2.54-3.52; head width/ dorsal interocular distance 1.37-1.57; head width/ventral interocular distance 2.38-3.03; mandibles with two apical teeth, but with no subapical tooth (Figs. 2C-D); median lobe slightly dorso-ventrally curved, visible in lateral view (Fig. 2O); aedeagal apodemes completely fused, evidently widened at the apex (Fig. 2O); spermatheca U-shaped, but notably cleft in the middle (Fig. 2P); known from Mexico; associated with Ceratozamia tenuis . P. mexicana sp. nov. - Elytron length/pronotal length 3.35-4.29; head width/ dorsal interocular distance 1.45-1.61; head width/ventral interocular distance 1.92-2.53; mandibles with two apical teeth, and one subapical tooth (Figs. 4C-D); median lobe evidently dorso-ventrally curved, visible in lateral view (Fig. 4O); aedeagal apodemes apparently fused at least $4 / 5$ basally, moderately widened at the apex (Fig. 
4O); spermatheca U-shaped, but only slightly cleft in the middle (Fig. 4P); known from Mexico; associated with Ceratozamia tenuis $P$. tenuis sp. nov.

\section{Description of species \\ Pharaxonotha mexicana Santiago-Jiménez sp. nov. Figs. 1-2 \\ http://zoobank.org/879D8CCA-AF5F-4594-ABE6- C7222DA8445C}

Diagnosis. Pharaxonotha mexicana can be easily distinguished from other Pharaxonotha species by a combination of characters: length 4.1-6.0 mm; mandibles with two apical teeth, but without subapical tooth (Figs. 2C-D); median lobe slightly dorso-ventrally curved, looking "V-shaped" (Fig. 2O); aedeagal apodemes fused completely, evidently widened at the apex (Fig. 2O); spermathecal "U-shaped" and notably cleft in the middle (Fig. 2P).

Description. Body in dorsal view elongate to oval (Fig. 1A); length 4.1-6.0 mm, width $1.68-2.42 \mathrm{~mm}$, greatest width near anterior $2 / 3$ of elytra together, length/width ratio 2.39 $2.53(\mathrm{~N}=10)$; in lateral view depressed (Fig. 1B), dorsally and ventrally slightly convex; color reddish-brown, head with darkest pigmentation, thorax (including pronotum and legs) and ventral intermediate, and elytra with lightest pigmentation, light reddish-brown and weakly transparent; sculpture uniformly and moderately densely punctulate on head and pronotum, although on head punctures are slightly thicker, on meso- and metaventrite punctures are coarser and thicker, moderately densely distributed; dorsal surface almost glabrous, but with yellowish distinguished setae moderately densely arranged on ventral surface and apex of pronotum, most notorious in apex of pronotum, base of mesoventrite, sternites, apex of tibiae, and tarsae.

Head - mouthparts. Clypeus plane, apically truncate, almost glabrous (Fig. 2A). Labrum short and transverse, apical margin is fringed with labral bristles (Fig. 2B). Mandibles (Figs. 2C-D) large, arcuate-triangular; apically with 2 narrowly superposed teeth, with a sulcus in outer margin visible in dorsal view, and with row of setae. Maxilla (Fig. 2E) with cardo apically expanded; stipes narrowly triangular, apically acute, partially overlapping with palpiger; galea (apically) and lacinia (inner side) with long, densely aligned setae; maxillary palp 4-segmented; palpomere I small, approximately $1 / 2$ as long as II; II large, longer than III, elongate-clavate; III less than $1 / 2$ the length of IV, equilateral; IV elongate-oval, apically densely papillate. Labium (Fig. 2F) with mentum trapezoidal, apically distinctly narrowed, ventral surface with sparse microsetae and two larger subcentral setae, apical margin with two separate strong emarginations to accommodate each labial palp, centrally with a projection to accommodate the ligula; ligula with palpiger projecting beyond mentum, paraglossae elongate-lobulate, apically with long, densely arranged setae; labial palps 3-segmented; palpomere I slightly longer than II, elongate; II small, widened to the apex; III large, elongate-oval, apically papillate. Head in dorsal view conical (Fig. 2A), apically narrowed, more abruptly narrowed at antennal insertions level, plane to very slightly convex, width 0.81-1.14 $\mathrm{mm}$; dorsal interocular distance 0.54-0.84 mm, head width/dorsal intraocular distance ratio 1.37-1.57 ( $\mathrm{N}=10)$; ventral interocular distance 0.32-0.48 $\mathrm{mm}$, head width/ventral interocular distance ratio 2.38-3.03 $(\mathrm{N}=10)$; dorsolateral margins bisinuate, supraocular striae absent, transverse line on vertex present, punctation coarse, with short, dark, obliquely oriented subcuticular suture (apodeme) on each side above antennal insertion, apical margin truncate, occiput with two stridulatory files; in lateral view slightly conical, with separate, angulate regions for eye (posterior) and antennal insertion (anterior), and with obtuse, lobulated to tuberculate, anteriorly directed projection at anteroventral edge; in ventral view, centrally, at eye level with a pit-like impression, ventrolateral margins emarginate, apically truncate. Antennae with 11 antennomeres (Fig. 2G), inserted laterally near anterodorsal margin of eye, about $1.1 \times$ the length of the pronotum, antennomere I (scape) fairly large, length greater than width, antennomeres II-III, slightly smaller, equilateral, antennomeres IV-VIII small, progressing sequentially from equilateral to slightly transverse; club 3 -antennomeres fairly large, light reddish-brown, with dense setation, IX and X similar in length, clavate, XI almost subquadrate, globular, slightly depressed, with fine dense pubescence. Eyes globular, protruded, with as many as 12 large black facets spanning from anterior to posterior margin, anterior margin slightly oblique, nearly straight.

Thorax. Pronotum (Fig. 2H) in dorsal view slightly transverse, length/width ratio $0.68-0.83(\mathrm{~N}=10)$, evenly convex, anterolateral edges weakly projected, angulate, not evenly rounded, posteriorly on each side without 1 narrow sulcus positioned at half distance between midline, but with a minute impression in the margin at the same position; posterior margin slightly arcuate, centrally projected; lateral edges straight to slightly arcuate, subparallel, with slightly elevated carina continuing to the posterior margin; anterior margin slightly arcuate, anterocentrally projected; in lateral view, hypomera almost trapezoidal, slightly convex and glabrate, with a projection at the posterior margin surrounding the procoxae, which is almost in contact with the prosternal process. Elytral epipleura almost glabrate, except in the subapical region where it presents yellowish setae; each elytron with two lateral patches of pseudopores, one at $1 / 4$ and the other at $1 / 2$ of the length of elytron (only visible on slides); with mesepisternum triangular; mesepimeron almost triangular; metanepisternum large, posteriorly slightly narrowed; metepimeron medium size (approx. 1/2 the width of the metanepisternum), nearly entirely covered by elytra. Prosternum in ventral view nearly evenly convex; lateral margins anteriorly distinctly diverging along suture; anterior margin straight to laterally arcuate, crenulate, with row of long, anteriorly directed yellow setae; procoxal cavities separated by double distance of breadth of antennal funicle, laterally closed, although posteriorly open. Mesoventrite (Fig. 2I) short, at the same level as metaventrite (not inflected); anterior margin with a small impression on each side of midline (visible on slide) to receive the prosternal process; mesocoxal cavities laterally closed. Metaventrite (Fig. 2J) long (2.2× longer than mesoventrite), laterally convex, centrally slightly impressed, with midline suture extending along posterior $2 / 3$, at posterior end between narrowly separated metacoxal cavities with small, rounded emargination. Metendosternite with lateral margins of stalk slightly diverging; lateral arms long and narrow, directed lateroventrally; dorsal furcal arms 
directed dorsally at a nearly $90^{\circ}$ to lateral arms, apically slightly widened; anterior tendons separated from median point by nearly $1 / 7$ of the distance towards base of furcal arms.

Legs fairly short and widened, similar in length and shape; procoxae small, approximately $1 / 2$ the length of the profemur, elongated, not globular (Fig. 2K); mesocoxae globular (Fig. 2L); metacoxa transversely elongate-oval, without distinct posterior face (Fig. 2M); trochanters apically obliquely formed; femora fairly stout, laterally compressed, ventrally with slightly concave, glabrate surface to receive tibiae; tibiae shorter than femora, protibia/profemur length ratio $0.76-0.80(\mathrm{~N}=3)$; protibia slightly arcuate, compressed, margins weakly carinate, narrowly triangularly widened towards apex, apical margin with a U-shaped incision, with rows of ca. $11(6+5)$ short and narrow spinules, with 2 spinules at inner (mesal) angle slightly larger, and 3 shorter spinules supported by small projection at outer (lateral) edge, this projection separated from rows of spinules by the U-shaped incision; tarsi 5-segmented, similar in length to tibiae, tarsomeres I-III ventrally with long, fine densely arranged, anteriorly directed setae; tarsomere I large, but slightly shorter than II, clavate; II and III slightly larger, similar in length, clavate; IV small, nearly $3 / 5$ the length of III, globular; V long and narrow, similar in length to I-III, apically slightly expanded; tarsal claws paired, simple.

Scutellar shield, transverse, posterior margin rounded but converging in a small point in the middle. Elytron (Fig. $2 \mathrm{~N}$ ) in dorsal view elongate-oval, elytra together length:width ratio 1.5-1.71 $(\mathrm{N}=10)$, greatest width half way along the structure; anterior margins nearly straight, with narrow anterior marginal line (cf. Chaves and Genaro 2005), angulate at midline; humeri small (not protruded), rounded; lateral margins slightly arcuate, subparallel along anterior $2 / 3$, posteriorly slightly converging, more strongly converging along posterior $1 / 3$; posterior margins subcontiguous; in lateral view slightly and evenly convex; 10 complete striae +1 short scutellary striole (with 9-11 punctures) extending along anterior 1/4 near midline; striae I-VI narrower than intervals, not grooved, punctures coarser in striae I-III, VII-X and punctures smooth in striae IV-VIII, subcircular, centrally without evident short setae, slightly irregularly spaced, intervals closer among striae VII-VIII and IX-X; striae appear non-obsolete along anterior and posterior $1 / 3$. Wings slightly longer than body, wing:body ratio 1.05-1.17 $(\mathrm{N}=4)$, elongate to oval, length:width ratio 2.8-3.6 ( $\mathrm{N}=4)$, greatest width near central region; costal margin almost straight, posterior margin slightly arcuate, with jugal area separated from anal region by a small V-shaped incision; all major veins present (compare with McHugh et al. 1997), but without anal cell (see Chaves and Genaro 2005); radial, medial and apical fields without evident maculations; macrosetae are visible at costal, anal and apical margins; microsetae are slightly visible on surface.

Abdomen. Venter in ventral view with 5 visible segments; anterior margin of the sternite III medially with distinct acute-triangular projection between metacoxal cavities, and anterolateral edges slightly projected; lateral margins arcuate-rounded; posterior margins slightly rounded to truncate, posteriorly converging; sternite III longer than IV, metasubcoxal lines absent; IV to VI similar in length; VII slightly longer than VI, posterior margin with row of short to fairly long, appressed, densely arranged yellow setae. Tergite VII with one patch of yellowish setae on each side of midline, posterior margin truncated with several rows of short yellowish setae. Pygidium (tergite VIII) in dorsal view trapezoidal, lateral margins almost straight, posterior margin slightly arcuate, with several rows of short yellowish setae; as long as ventral sternite VII (visible on slide), slightly convex, narrow.

Terminalia. Tergite IX (proctiger) reduced, sternite IX (spiculum gastrale) appearing trilobed, lateral lobes (paraprocts) with two lateral, long and narrow, anteriorly converging and connected apodemes. Tegmen (Fig. 2O) with anterior region (2/4) ring-like, posterior region (2/4) sheath-like (slightly convex, enclosing median lobe), weakly sclerotized triangular, centrally with large oval perforation to receive median lobe; lateral margins posteriorly gradually converging; posterior margin slightly arcuate, dorsally with 2 large elongate, subparallel apically setose parameres. Aedeagus (Fig. 2O) with median lobe in dorsal view elongate $1 / \mathrm{w}=3.4$, lateral margins subparallel to slight sinuate, apically narrowed, rounded, symmetrical; apical $1 / 2$ more strongly sclerotized; in lateral view slightly deflexed looking V-shaped, basal 3/5 broader, apical 2/5 narrowing to an acute apex, with distinct internal space; internal sac membranous, with very long, variously wound flagellum; aedeagal apodemes completely fused, distinctly longer than median lobe, narrow and only slightly curved at base (in lateral view), to the apex nearly straight, apex evidently widened (Fig. 2O).

Description - female. Similar to male (see description above); with exception of the pygidium with posterior margin less arcuate.

Sternite VIII (spiculum ventrale) present. Tergum IX (paraprocts) with oblique longitudinal separation, internal margins slightly more strongly sclerotized. Tergum X (epiprocts) and gonocoxites more or less triangular, posteriorly gradually narrowed, apices of gonocoxites laterally with small concave impression maintaining some setae; gonostyli short, narrow, posteriorly diverging and not visible broadened, with minute setae. Vulvar tube membranous, posteriorly expanded. Spermatheca (Fig. 2P) narrowed for half of the length, basal and apical half more or less equally broad; deflected by nearly $180^{\circ}$, C-shaped, apically convex, basally with a long point, and laterally with accessory gland.

Variation. Basically there are differences in size, a slightly lighter and more heterogeneous pigmentation in teneral specimens, and variation in the shape, depth, and color of the elytral punctures.

Type material. Male, holotype (IEXA), original label: "MÉXICO: Veracruz, Coacoatzintla, Tlachinola, 11.I.2016, BMM pert., ex. cono m\#8 C. tenuis, $1426 \mathrm{~m}, 19^{\circ} 38^{\prime} 52.9^{\prime \prime} \mathrm{N}$, 96057'13.3”W, F. Nicolalde, L. Martínez, Q. Santiago". Paratypes (25 IEXA, 20 CNIN), same label information as holotype: 1 male, 3 females (on slide), 16 (pinned); same label information, except for: ex. cone $\mathrm{m} \# 24,1$ female (on slide), 2 (pinned); same label information, except for: 12.II.2016, ex. cone $\mathrm{m} \# 35$ (4 pinned); same label information, except for: ex. cone m\#42, 4 (pinned); same label information, except for: 15.II.2016, col. in the twilight, 4 females (on slide), 5 (pinned); same label information, except 
for: ex. cone $\mathrm{f} \# 25,2$ (pinned); same label information, except for: 19.II.2016, ex. cone f\#31, 1 (ethanol); same label information, except for: 23.II.2016, ex. cone f\#25, 1 (ethanol); same label information, except for: ex. cone f\#31, 1 (ethanol).

Etymology. The species epithet makes reference to Mexico, country where C. tenuis is endemic.

Bionomics. Adults of Pharaxonotha mexicana were collected consistently on the pollen strobilus of $C$. tenuis, with more individuals present at the open pollen (MartínezDomínguez et al. 2018). Larvae were found on decaying pollen strobilus and on the soil where fragments had fallen.

\section{Pharaxonotha tenuis Santiago-Jiménez sp. nov. Figs. 3-4 \\ http://zoobank.org/45718718-4193-4E8E-979E- 5DC4B21EB808}

Diagnosis. Pharaxonotha tenuis can be easily distinguished from other congeners by a combination of characters: length 3.6-5.32 mm; mandibles with two apical teeth and one subapical tooth (Figs. 4C-D); median lobe evidently dorso-ventrally curved, "L-shaped" appearance (Fig. 4O); aedeagal apodemes apparently fused at least 4/5 basally, moderately widened at the apex (Fig. 4O); spermatheca "U-shaped", but only slightly cleft in the middle (Fig. 4P).

Description. Body in dorsal view elongate to oval (Fig. 3A); length 3.6-5.32 mm, width 1.41-2.1 mm, greatest width around $2 / 3$ that of elytra together, length:width ratio $2.4-$ $2.74(\mathrm{~N}=10)$; in lateral view depressed (Fig. 3B), dorsally and ventrally slightly convex; color yellowish-brown, head and, in some specimens, pronotum with slightly darkest pigmentation, rest of body with lightest pigmentation, light yellowish-brown and weakly transparent; sculpture uniformly and moderately densely punctulate on head and pronotum, although on head punctures are slightly thicker, on meso- and metaventrite punctures are slightly coarser and thicker, but apparently more densely distributed on mesoventrite; dorsal surface almost glabrous except for the elytra which show some yellowish setae; moreover, with distinguished yellowish setae moderately densely arranged on ventral surface, apex of pronotum and elytra, most notorious on apex of pronotum, base of mesoventrite, sternites, tibiae, tarsae, and femur.

Head - mouthparts. Clypeus plane, apically truncate, glabrous (Fig. 4A). The labrum is short and transverse, apical margin is fringed with labral bristles (Fig. 4B). Mandibles (Figs. 4C-D) large, arcuate-triangular; apically with 2 narrowly superposed teeth and 1 minute tooth in dorsal view, with a sulcus in outer margin, and with row of setae. Maxilla (Fig. 4E) with cardo apically slightly expanded and setose; stipes narrowly triangular, apically acute, partially overlapping with palpiger; galea (apically) and lacinia (inner side) with long, densely aligned setae; maxillary palp 4-segmented, palpomeres 2-3 with row of sparsely arranged, subapically positioned setae; palpomere I very small, nearly $1 / 4$ the length of II, elongate; II large, longer than III, elongate-clavate; III large, nearly $1 / 2$ the length of IV, clavate; IV elongate-oval, apically densely papillate. Labium (Fig. 4F) with mentum trapezoidal, apically distinctly narrowed, ventral surface with sparse microsetae and two larger subcentral setae, apical margin with two slight emarginations to accommodate each labial palp, centrally with almost small projection to accommodate the ligula; ligula with palpiger projecting beyond mentum, paraglossae elongate-lobulate, apically with long, densely arranged setae; labial palps 3-segmented; palpomere I small, almost as long as II, elongate; II small, widened to the apex; III large, elongate-oval, apically papillate. Head in dorsal view conical (Fig. 4A), apically narrowed, more abruptly narrowed at antennal insertions level, plane to very slightly convex, width $0.72-1.0 \mathrm{~mm}$; dorsal interocular distance 0.48- $0.68 \mathrm{~mm}$, head width:dorsal intraocular distance ratio 1.45-1.61 ( $\mathrm{N}=10)$; ventral interocular distance 0.29-0.42 $\mathrm{mm}$, head width:ventral interocular distance ratio 1.92$2.53(\mathrm{~N}=10)$; dorsolateral margins bisinuate, supraocular striae absent, transverse line on vertex present, punctation coarse, with short, dark, obliquely oriented subcuticular suture (apodeme) on each side above antennal insertion, apical margin truncate, occiput with two stridulatory files; in lateral view slightly conical, with separate, angulate regions for eye (posterior) and antennal insertion (anterior), and with obtuse, lobulated to tuberculate, anteriorly directed projection at anteroventral edge; in ventral view slightly concave at eye level, centrally without a visible pit-like impression, ventrolateral margins emarginate, apically truncate. Antennae with 11 antennomeres (Fig. $4 \mathrm{G})$, inserted laterally near anterodorsal margin of eye, about $1.1 \times$ the length of the pronotum, antennomere I (scape) fairly large, longer than wide, antennomeres II-III, slightly smaller, elongate, antennomeres IV-VIII small, progressing sequentially from slightly long to transverse; club 3-antennomeres fairly large, light reddish-brown, with dense setation, IX and X similar in length, clavate, XI slightly longer, globular, slightly depressed, with fine dense pubescence. Eyes globular, protruded, with as many as 12 large black facets spanning from anterior to posterior margin, anterior margin slightly oblique, nearly straight.

Thorax. Pronotum (Fig. 4H) in dorsal view slightly transverse, length:width ratio $0.62-0.77(\mathrm{~N}=10)$, evenly convex, anterolateral edges weakly projected, angulate, not evenly rounded, posteriorly on each side with 1 almost imperceptible sulcus trace positioned halfway between midline and outer margin, which finishes close to posterior margin in a small impression; posterior margin slightly arcuate, centrally projected; lateral edges straight to slightly arcuate, subparallel, with slightly elevated carina continuing to the posterior margin; anterior margin almost straight; in lateral view, hypomera is almost trapezoidal, slightly convex and glabrate, with a projection at posterior margin surrounding the procoxae, which is almost in contact with prosternal process. Elytral epipleura with scarce setae, except in the subapical region where dense yellowish setae are presented; each elytron with two lateral patches of pseudopores, one at $1 / 4$ and the other at $1 / 2$ of the length of elytra (only visible on slides); with mesepisternum triangular; mesepimeron almost triangular; metanepisternum large, posteriorly slightly narrowed; metepimeron medium size (approximately half of the width of the metanepisternum), nearly entirely covered by elytra. Prosternum in ventral view nearly evenly convex; lateral margins anteriorly distinctly diverging along suture; anterior margin straight to laterally arcuate, crenulate, with row of long, anteriorly directed yellow setae; procoxal cavities 
separated by double distance of breadth of antennal funicle, laterally closed, although posteriorly open. Mesoventrite (Fig. 4I) short, at the same level as metaventrite (not inflected); anterior margin with a small impression on each side of midline (visible on slide) to receive the prosternal process; mesocoxal cavities laterally closed. Metaventrite (Fig. 4J) long $(2.3 \times$ longer than mesoventrite), laterally convex, centrally slightly impressed, with midline suture extending along posterior $2 / 3$, at posterior end between narrowly separated metacoxal cavities with small, rounded emargination. Metendosternite with lateral margins of stalk slightly diverging; lateral arms long and narrow, directed lateroventrally; dorsal furcal arms directed dorsally at a nearly $90^{\circ}$ to lateral arms, apically slightly widened; anterior tendons separated from median point by nearly $1 / 2$ of the distance towards base of furcal arms.

Legs fairly short and widened, similar in length and shape; procoxae small, approx. 2/3 of length of profemur, elongated, not globular (Fig. 4K); mesocoxae globular (Fig. 4L); metacoxa transversely elongate-oval, without distinct posterior face (Fig. 4M); trochanters apically obliquely formed; femora fairly stout, laterally compressed, ventrally with slightly concave, glabrate surface to receive tibiae; tibiae shorter than femora, protibia/profemur length ratio 0.78-0.81 ( $\mathrm{N}=4)$; protibia slightly arcuate, compressed, margins weakly carinate, narrowly triangularly widened towards apex, apical margin with a U-shaped incision, with rows of $c a .19(11+8)$ short and narrow spinules, with 2 spinules at inner (mesal) angle slightly larger, and 2 shorter spinules supported by small projection at outer (lateral) edge, this projection separated from rows of spinules by the U-shaped incision; tarsi 5-segmented, similar in length to tibiae, tarsomeres I-III ventrally with long, fine densely arranged, anteriorly directed setae; tarsomeres I slightly larger than II and III, clavate; II and III similar in length, clavate; IV small, nearly 0.5 as long as III, more or less globular; V long and narrow, subequal or only slightly shorter than II + III, apically very slightly expanded; tarsal claws paired, simple.

Scutellar shield, transverse, posterior margin rounded but converging in a small point in the middle. Elytron (Fig. 4N) in dorsal view elongate-oval, elytra together length / width ratio 1.70-1.82 $(\mathrm{N}=10)$, greatest width at half; anterior margins nearly straight, with narrow anterior marginal line (cf. Chaves and Genaro 2005), angulate at midline; humeri small (not protruded), rounded; lateral margins slightly arcuate, subparallel along anterior $2 / 3$, posteriorly slightly converging, more strongly converging along posterior $1 / 3$; posterior margins subcontiguous; in lateral view slightly and evenly convex; 10 complete striae +1 short scutellary striole (with 9-13 punctures) extending along anterior $1 / 5$ near midline; striae I-VI narrower than intervals, not grooved, punctures coarser in striae I-III, VII-X, and punctures smooth in striae IV-VIII, subcircular, slightly irregularly spaced, intervals closer among striae VII-VIII and IX-X, with small setae in fine punctures located on intervals; striae not appearing obsolete along anterior and posterior $1 / 3$. Wings as long as body or slightly longer than body, wing:body ratio $1.0-1.13(\mathrm{~N}=4)$, elongate to oval, length:width ratio 2.29-2.87 ( $\mathrm{N}=4)$, greatest width near central region; costal margin slightly sinuate, posterior margin slightly arcuate, with jugal area separated from anal region by a small V-shaped incision; all major veins present (compare with McHugh et al. 1997), but without anal cell (see Chaves and Genaro 2005); radial, medial and apical fields without evident maculations; macrosetae are visible at costal, anal and apical margins; microsetae are slightly visible on surface.

Abdomen. Venter in ventral view with 5 visible segments; anterior margin of the sternite III with distinct acute-triangular projection medially between metacoxal cavities, and anterolateral edges slightly projected; lateral margins arcuate-rounded, posterior margins slightly rounded to truncate, posteriorly converging; sternite III longer than IV, metasubcoxal lines absent; IV-VI similar in length; VII slightly longer than VI, posterior margin with row of short, appressed, densely arranged yellow setae. Tergite VII with one patch of yellowish setae on each side of midline. Pygidium (tergite VIII) in dorsal view trapezoidal, lateral margins slightly arcuate, posterior margin slightly arcuate, with several rows of short yellowish setae; as long as the sternite VII (visible on slide), slightly convex, narrow.

Terminalia. Tergite IX (proctiger) reduced, sternite IX (spiculum gastrale) appearing trilobed, lateral lobes (paraprocts) with two lateral, long and narrow, anteriorly converging and connected apodemes. Tegmen (Fig. 4O) with anterior region (2/4) ring-like, posterior region (2/4) sheath-like (slightly convex, enclosing median lobe), weakly sclerotized triangular, centrally with large oval perforation to receive median lobe; lateral margins posteriorly gradually converging; posterior margin slightly arcuate, dorsally with 2 large elongate, subparallel apically setose parameres. Aedeagus (Fig. 4O) with median lobe in dorsal view elongate $1 / \mathrm{w}=3.6$, lateral margins subparallel to slight sinuate, apically narrowed, rounded, symmetrical; apical 3/4 more strongly sclerotized; in lateral view strongly deflexed appearing L-shaped, basal 4/5 broader, apical 1/5 narrowing to the acute apex, with distinct internal space; internal sac membranous, with very long, variously wound flagellum; aedeagal apodemes apparently fused at least $4 / 5$, distinctly longer than median lobe, narrow and only slightly curved at base (in lateral view), to the apex nearly straight, apex widened (Fig. 4O).

Description - female. Similar to male (see description above); with exception of the pygidium with posterior margin truncate.

Sternite VIII (spiculum ventrale) present. Tergum IX (paraprocts) with oblique longitudinal separation, internal margins slightly more strongly sclerotized. Tergum X (epiprocts) and gonocoxites more or less triangular, posteriorly gradually narrowed, apices of gonocoxites laterally with small concave impression maintaining some setae; gonostyli short, narrow, posteriorly diverging and not visible broadened, with minute setae. Vulvar tube membranous, posteriorly expanded. Spermatheca (Fig. 4P) narrowed in apical half, broader in basal half; deflected by nearly $180^{\circ}, \mathrm{C}$-shaped, apically convex, basally with a long point, and laterally with accessory gland.

Variation. Basically there are differences in size, a slightly lighter and more heterogeneous pigmentation in teneral specimens, and variation in the shape, depth, and color of the elytral punctures. Some specimens show yellow setae on submentum, and some a submental suture visible as a depressed darkened area. 
Type material. Male, holotype (IEXA), original label: "MÉXICO: Veracruz, Coacoatzintla, Tlachinola, 11.I.2016, BMM pert., ex. cono m\#8 C. tenuis, $1426 \mathrm{~m}, 19^{\circ} 38^{\prime} 52.9^{\prime} \mathrm{N}$, 96057'13.3”W, F. Nicolalde, L. Martínez, Q. Santiago". Paratypes (11 IEXA, 11 CNIN), same label information as male holotype: 1 male, 2 females (on slide), 17 (pinned); same label information, except for: ex. cone $\mathrm{m} \# 24,1$ female (on slide); same label information, except for: 12.II.2016, ex. cone m\#35 1 female (on slide).

Etymology. The species epithet makes reference to Ceratozamia tenuis, which is the cycad species where the new species of Pharaxonotha was collected.

Bionomics. Adults of Pharaxonotha tenuis were collected consistently on the pollen strobilus of C. tenuis, with more individuals present at the open pollen (MartínezDomínguez et al. 2018). Larvae were found on decaying pollen strobilus and on the soil where the fragments had fallen.

\section{DISCUSSION}

In recent years, several species of pollinators from Asia, Neotropics, and North America have been collected from Cycas (Old World) and Zamia (New World) (Norstog et al. 1986; Tang 1987; Pakaluk 1988; Norstog et al. 1992; Tang et al. 1999). More recently, several species from Asia have been described or assigned to the new genus Cycadophila (Xu et al. 2015; Skelley et al. 2017), or some species of Pharaxonothinae were analyzed using $16 \mathrm{~S}$ marker (Tang et al. 2018). However, some species of Pharaxonotha remain undescribed, indicating the need for further taxonomic study (Leschen 2003). Recently, Skelley et al. (2017) conducted a revision of Cycadophila; however, they recognized this genus based on morphology, where they included only some molecular characters as additional information, but the monophily was not tested. More recently (Tang et al. 2018) mentioned a new genus of Pharaxonothinae; however, they didn't describe or give morphological characters to distinguish this of Cycadophila and Pharaxonotha. The tree of maximum likelihood presented by Skelley et al. (2017) shows Cycadophila as sister clade of Pharaxonotha; however, it is weakly supported (bootstrap 37) and the subgenus C. (Strobilophila) Skelley, Xu and Tang was recovered as paraphyletic. At present, it is impossible to define the limits between Cycadophila, Pharaxonotha, and new genus of Pharaxonothinae since more taxa must be included through study. Several characters used by Skelley et al. (2017) to distinguish Cycadophila from other Pharaxonothinae are also present in Pharaxonotha; for example: the head surface with transverse occipital ridge (vertexal line), large eyes that encroach upon head ventrally, supraocular striae present, with a remnant of the submental gular suture visible to variously depressed, and the lack of abdominal calli. It is therefore necessary to describe more taxa, mainly those associated with Ceratozamia hosts, in order to conduct an extensive analysis that includes more taxa and another set of data (i.e. nuclear genes) to adequately test the monophily of this group. The genus Ceratozamia has been poorly studied; however, some researchers (Martínez-Domínguez et al. 2016, 2017a, b) have recently explored this genus. Here, we describe two new species of Pharaxonotha associated with $C$. tenuis, and we are being conservative in the use of Pharaxonotha concept used by
Leschen (2003), since we consider that Cycadophlia will be a junior synonymy of Pharaxonotha when more of its taxa are described from other regions of Mexico. Finally, in the near future, the description and phylogenetic analysis of new species of Pharaxonotha will contribute to the knowledge of Pharaxonothinae, elucidating both systematic and biogeographical aspects.

\section{ACKNOWLEDGMENTS}

We are greatly indebted to the local inhabitants of Coacoatzintla and Tlachinola for their permission to conduct this study on their properties. The first author is very grateful to colleagues for their support at the Facultad de Biología, Universidad Veracruzana and Instituto de Ecología, A.C., particularly M. Morales, R. Ortega and R. Novelo for the use of the microscopes. The first author thanks A. Valencia for comments and grammatical corrections. Finally, we thank K. MacMillan and two anonymous reviewers for their valuable comments that have improved the document.

\section{LITERATURE CITED}

Chaves, R. and J. A. Genaro. 2005. A new species of Pharaxonotha (Coleoptera: Erotylidae), probable pollinator of the endangered Cuban cycad, Microcycas calocoma (Zamiaceae). Insecta Mundi, 19 (3): 143-150.

Franz, N. M. and P. E. Skelley. (2008) Pharaxonotha portophylla (Coleoptera: Erotylidae), new species and pollinator of Zamia (Zamiaceae) in Puerto Rico. Caribbean Journal of Science, 44 (3): 321-333.

Leschen, R. A. B. 2003. Erotylidae (Insecta: Coleoptera: Cucujoidea): phylogeny and review. Fauna of New Zealand, 47: 1-108.

Leschen, R. A. B. and P. E. Skelley. 2002. Languriidae. (pp. 343-347). In: Arnett, R. H. J., M. C. Thomas, P. E. Skelley and J.H. Frank (Eds.). American Beetles. Polyphaga: Scarabaeoidea through Curculionoidea. CRC Press, Boca Raton, Florida.

Leschen, R. A. B., P. E. Skelley and J. V. McHugh. 2010. 10.7 Erotylidae Leach 1815. (pp. 311-319). In: Leschen, R. A. B., R. G. Beutel and J. F. Lawrence (Eds.) Coleoptera beetles, vol. 2: morphology and systematics (Elateroidea, Bostrichiformia, Cucujiformia partim). Handbuch der Zoologie/Handbook of Zoology IV/39. Walter de Gruyter, Berlin, New York.

Mchugh, J. V., C. J. Marshall and F. L. Fawcett. 1997. A study of adult morphology in Megalodacne heros ( Say ) (Coleoptera: Erotylidae). Transactions of the American Entomological Society (1890-), 123(4): 167-223.

Martínez-Domínguez, L., F. Nicolalde-Morejón, F. VergaraSilva and D. W. Stevenson. 2016. Integrative taxonomy of mexican cycads: biogeography, morphology and DNA barcoding corroborate a new sympatric species in Ceratozamia (Zamiaceae). Phytotaxa, 268(1): 025-045.

Martínez-Domínguez, L., F. Nicolalde-Morejón, F. Vergara-Silva, D. W. Stevenson and E. del Callejo. 2017a. Cryptic diversity, sympatry, and other integrative taxonomy scenarios in the Mexican Ceratozamia miqueliana complex (Zamiaceae). Organisms Diversity \& Evolution, 17: 727-752.

Martínez-Domínguez, L., F. Nicolalde-Morejón and D. W. Stevenson. 2017b. Qualitative and quantitative morphological evidence for recognition of a new 
species within Ceratozamia (Zamiaceae) from Mexico. Phytotaxa, 317(1): 017-028.

Martínez-Domínguez, L., F. Nicolalde-Morejón, D. W. Stevenson and Santiago-Jiménez, Q. 2018. Conceptos taxonómicos, fenología y epefitismo: el caso de Ceratozamia tenuis (Zamiaceae). Taxonomic concepts, phenology and epiphytism: the case of Ceratozamia tenuis (Zamiaceae). Revista Mexicana de Biodiversidad, 89: 331-339.

Norstog, K. J., P. K. S. Fawcett and A. P. Vovides. 1992. Beetle pollination of two species of Zamia: evolutionary and ecological considerations. The Palaeobotanist, 41: $149-158$.

Norstog, K. N., D. W. Stevenson and K. J. Niklas. 1986. The role of beetles in the pollination of Zamia furfuraceae L. fil. (Zamiaceae). Biotropica, 18(4): 300-306.

Pakaluk, J. 1988. Review of the New World species of Pharaxonota Reitter (Coleoptera: Languriidae). Revista de Biologia Tropical, 36(2B): 447-451.

Santiago-Jiménez, Q. J. 2010. Revision of the genus Falagonia (Coleoptera: Staphylinidae: Aleocharinae: Lomechusini ), with description of related genera. Sociobiology, 55(3): 643-723.

Skelley, P., G. Xu, W. Tang, A. J. Lindström, T. Marler, J. S. Khuraijam, R. Singh, P. Radha and S. Rich. 2017. Review of Cycadophila Xu, Tang \& Skelley (Coleoptera: Erotylidae: Pharaxonothinae) inhabiting Cycas (Cycadaceae) in Asia, with descriptions of a new subgenus and thirteen new species. Zootaxa, 4267(1): 001-063.

Recibido: 4 de abril de 2018

Aceptado: 17 de julio de 2018

Primero en línea: 20 de septiembre 2018

Online First Publication: 20th September 2018

\section{A}

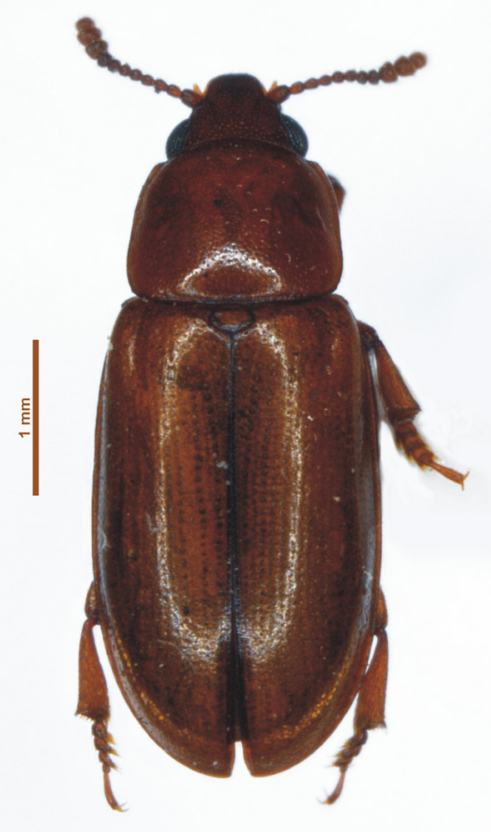

Slipinski, S. A., R. A. B. Leschen and J. F. Lawrence. 2011. Order Coleoptera Linnaeus, 1758. (pp. 203-208). In: Zhang, Z.-Q. (Ed.) Animal biodiversity: an outline of higher-level classification and survey of taxonomic richness. Zootaxa, (3148). Magnolia Press, Auckland, New Zealand.

Tang, W. 1987. Insect pollination in the cycad Zamia pumila (Zamiaceae). American Journal of Botany, 74(1): 9099.

Tang, W., R. G. Oberprieler and S.-L. Yang. 1999. Beetles in cones of Asian Cycas: diversity, evolutionary patterns, and implications for Cycas taxonomy. (pp. 280-297). In: Chen, C. J. (Ed.). Biology and conservation of cycads. Proceedings of the Fourth International Conference on Cycad Biology. International Academic Publishers, Beijing.

Tang, W., G. Xu, C. W. O’Brien, Charles, M. Calonje, N. M. Franz, M. A. Johnston, A. Taylor, A. P. Vovides, M. A. Pérez-Farrera, S. H. Salas-Morales, J. C. Lazcano-Lara, P. Skelley, C. Lopez-Gallego, A. Lindström and S. Rich. 2018. Molecular and morphological phylogenetic analyises of the New World cycad beetles: what they reveal about cycad evolution in the New World. Diversity, 10 (38): 1-26.

Wanat, M. 2007. Alignment and homology of male terminalia in Curculionoidea and other Coleoptera. Invertebrate Systematics, 21(2): 147-171.

Xu, G., W. Tang, P. Skelley, N. Liu and S. Rich. 2015. Cycadophila, a new genus (Coleoptera: Erotylidae: Pharaxonothinae) inhabiting Cycas debaoensis (Cycadaceae) in Asia. Zootaxa, 3986(3): 251-278.

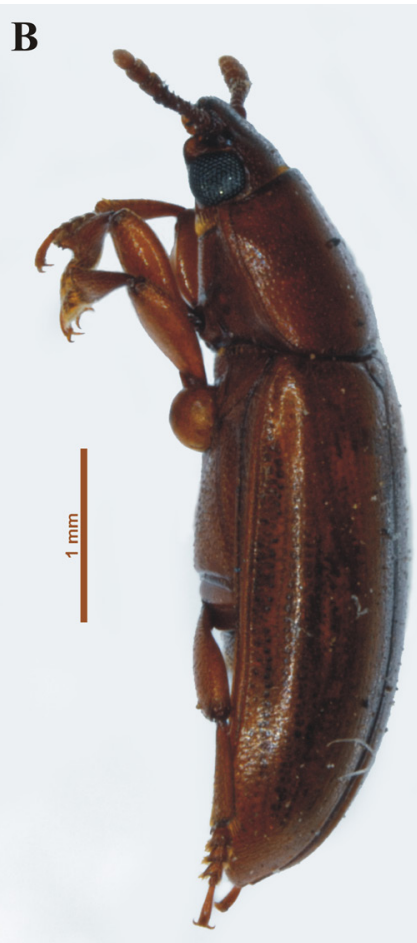

Figure 1. Photographs of Pharaxonotha mexicana sp. nov., paratype: A) dorsal habitus; B) lateral habitus. 

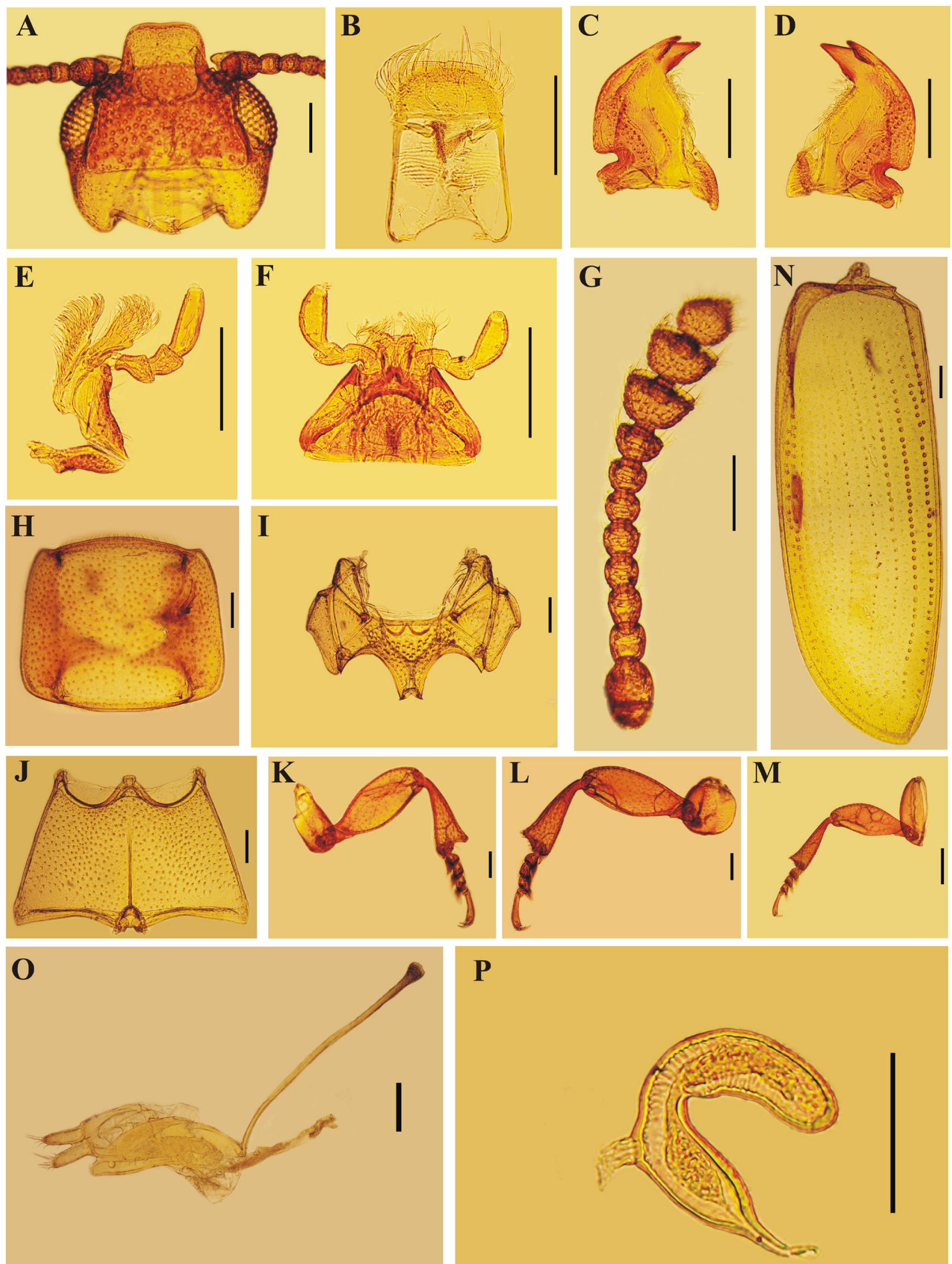

Figure 2. Structures of Pharaxonotha mexicana sp. nov. A) head, dorsal view; B) labrum, dorsal view; C) right mandible, ventral view; D) left mandible, ventral view; E) right maxilla, dorsal view; F) mentum and labial palpi, ventral view; G) antenna; H) pronotum, dorsal view; I) mesoventrite, ventral view; J) metaventrite, ventral view; K) proleg, internal view; L) mesoleg, internal view; M) metaleg, internal view; N) left elytron; O) male genitalia; P) spermatheca. Scale bars $0.2 \mathrm{~mm}$, except Figure 2P, where scale bar is $0.1 \mathrm{~mm}$. 
A

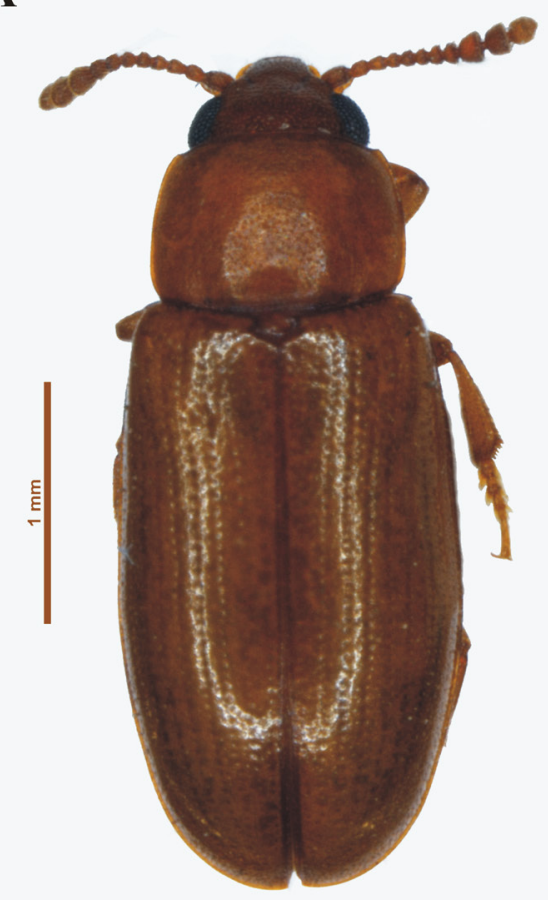

B

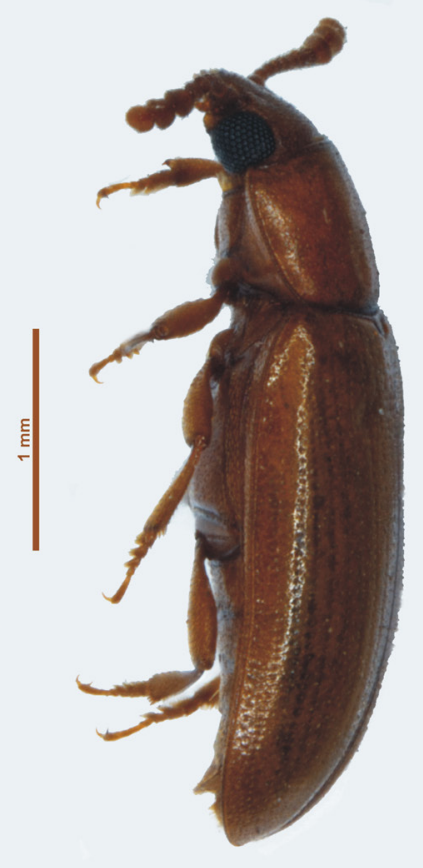

Figure 3. Photographs of Pharaxonotha tenuis sp. nov., paratype: A) dorsal habitus; B) lateral habitus. 

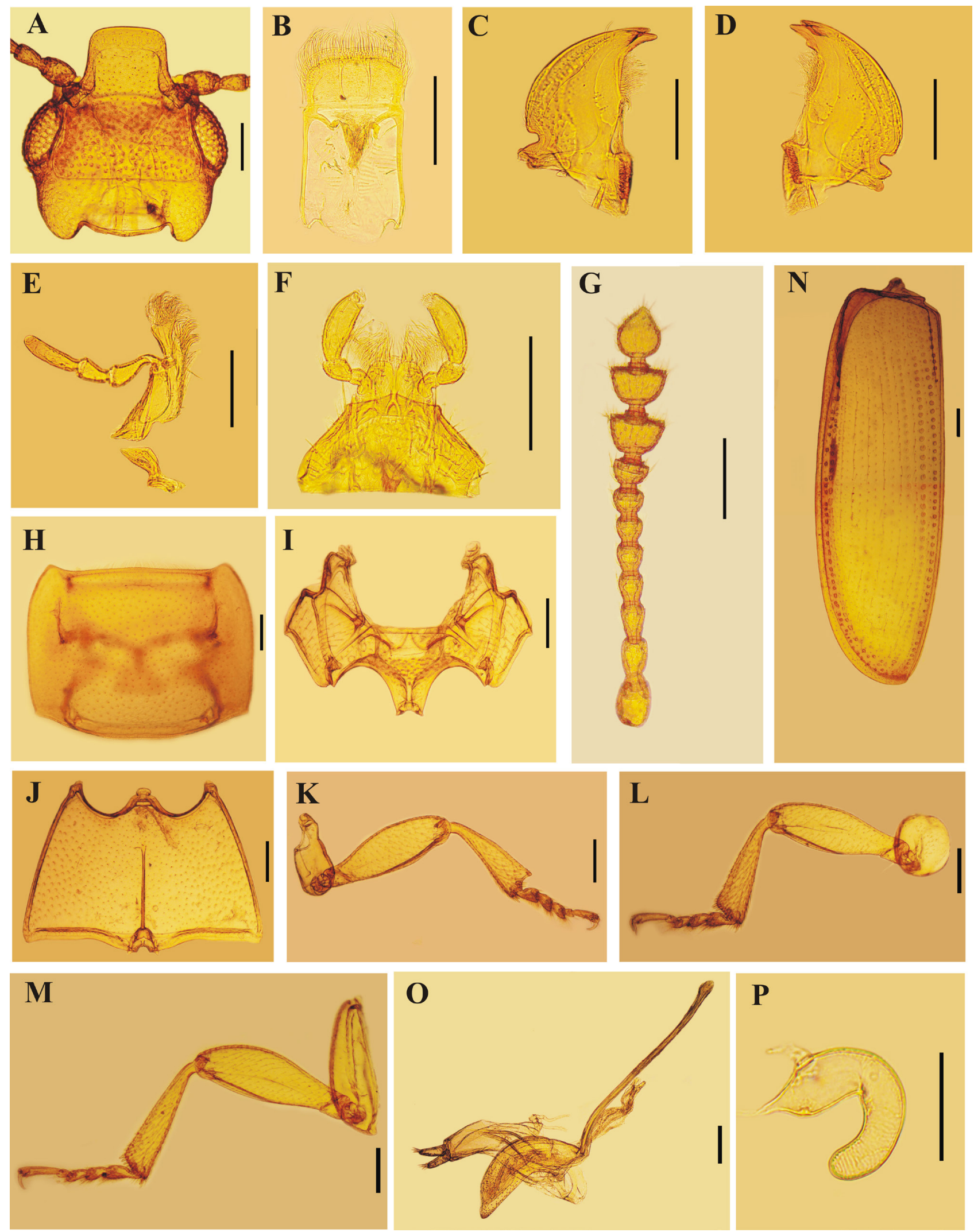

Figure 4. Structures of Pharaxonotha tenuis sp. nov. A) head, dorsal view; B) labrum, dorsal view; C) right mandible, ventral view; D) left mandible, ventral view; E) left maxilla, dorsal view; F) mentum and labial palpi, ventral view; G) antenna; H) pronotum, dorsal view; I) mesoventrite, ventral view; J) metaventrite, ventral view; K) proleg, internal view; L) mesoleg, internal view; M) metaleg, internal view; N) left elytron; O) male genitalia; P) spermatheca. Scale bars $0.2 \mathrm{~mm}$, except Figure 4P, where scale bar is $0.1 \mathrm{~mm}$. 